\title{
Research and Practice of Mechanical Engineering Training Platform Facing the Applied Talents Cultivation
}

\author{
JIAN Zhenghao \\ School of mechanical and Vehicular Engineering, Nanchang Institute of Technology \\ jianzhenghaojx@163.com
}

\begin{abstract}
Keywords: Engineering training centre, innovation, platform, mechanical system
Abstract. Cultivation of undergraduate talents needs to strengthen the teaching of basic theory, and at the same time, give prominence to the practice and application ability of exercise and training. Engineering training practice teaching is an important part of higher education, cultivating comprehensive, innovative, high-quality engineering and technical talents with innovative consciousness and innovative ability, good brain, knowing how to practice, understand the design and operation through the engineering training practice is the urgent needs of the development of China's economic construction. Engineering training center is engineering practice teaching base to train college students to participate in the industry, and is also the students' autonomous learning and the extracurricular activities of science and technology of modern public teaching support platform. Therefore, the construction of a basic content of modern industrial system is to meet the need of modern engineering technology development of university engineering training center.
\end{abstract}

\section{What is applied talents}

Basic concept and essence of applied talents. The concept of applied talents is the result of the development of science and technology promoting social division of labor refining. Division of agriculture and animal husbandry, handicraft industry separated from agriculture, businessmen formed a separate social class have been three significant social division of labor in human history. Scientific and technological work becoming a single industry marked is the fourth big social division of labor in human history. Among the scientific and technological work, in terms of the talent we need, and can be divided into research-oriented talents to find knowledge; applied talents to make use of the knowledge and skilled talents to complete the specific operation.

Applied talents mainly under the certain theoretical specification being the guide, work in the academic research, its task is to transform the abstract theory of symbolic into specific operation idea or product configuration, applying knowledge to practice. Applied talents, in other words, is skilled in theoretical study of academic talent and good at that corresponds to the actual operation of skilled talents, have both enough theoretical basis and professional, and can integrate theory with practice of applying knowledge to practical talents. The main task of the academic talent is committed to the objective laws in the field of natural science and social science into scientific principle; the main task of applied talents is to apply science directly in the field of social practice so as to create direct economic benefits for the society and material wealth. Applied talents is the core of "use", the essence is to apply, "use" is the foundation of knowledge and ability, "with" object is the social practice, "with" the purpose is to meet the social demand, promoting social progress.

Our country is in the critical period of economic transformation, especially proposed the goals of "new industrialization, informationization, urbanization and agricultural modernization" in the 18th of the Party, new modernization requires transformation path of industrialization, namely, the transformation of from traditional industrialization to new industrialization. Characteristics of new type industrialization is high technological content, good economic benefits, low resources consumption, little environmental pollution and making full advantages of human resource. Economic development has changed from the factors driving, investment-driven to innovation-driven, which must have a solid professional foundation, strong technical strength, outstanding practice ability to really put this to use as a support of the high-quality practical talents. 
Levels of applied talent. As an independent type of talents, applied talent has a layered system, roughly can be divided into: applied undergraduate talents and applied high talents; among the two types, the applied high talents mainly refer to applied master and doctor. Applied undergraduate talents, by contrast, draw more attention to application of the basic knowledge and theory, applied talents draw attention to the application of knowledge at the same time, focus on applied research to grasp the core technology, promote the development of applied science and technology quality, and play a role in the application of theory of innovation and breakthrough.

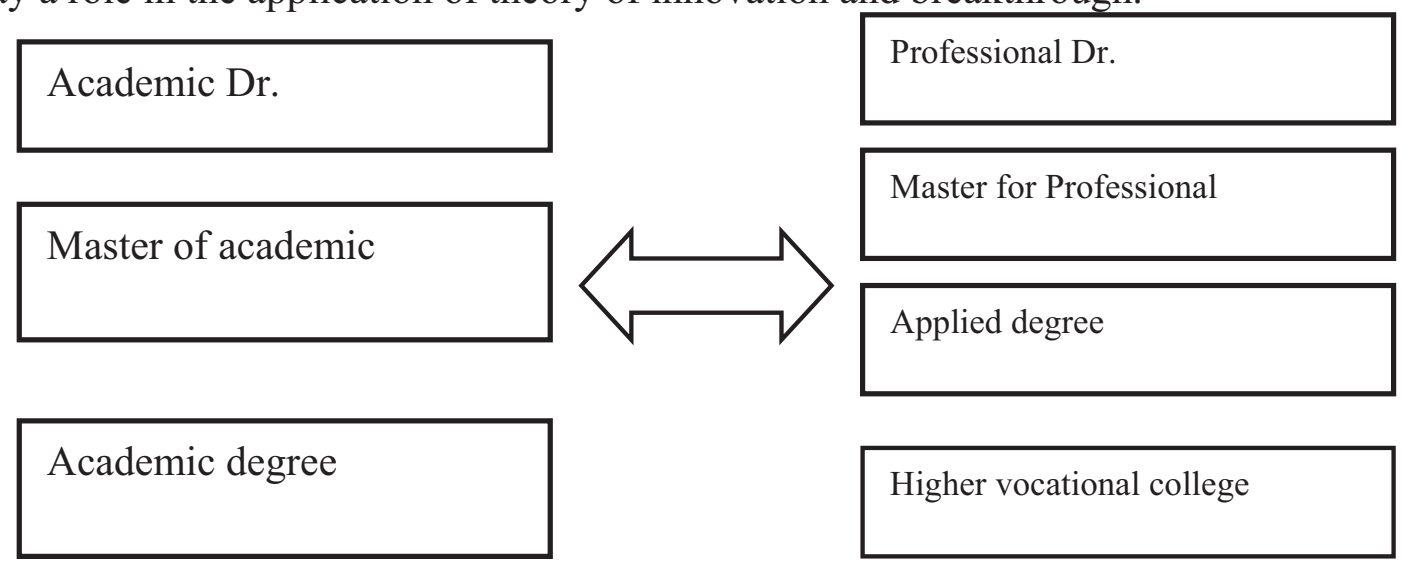

Chart 1 the chart of the Higher educated talents cultivation

If understanding applied talents from a broader sense, we can also think high skilled person is a hierarchy of applied talents system. Hence applied talents system should contain high skilled talents, applied undergraduate talents and applied talents. The corresponding higher education training system is consisted by four levels: the vocational, applied undergraduate, masters, professional doctorate. Our country's government is paying more attention to and actively constructing the applied talent cultivation system. Chart 1 is a traditional academic talent cultivation system of our country's higher education talent cultivation system model, applied talents cultivation system with independent academic talents training system and connectivity, the figure can vividly tell us that our country's higher education talent cultivation system could be called the higher education personnel training system.

\section{Constructing elements of the applied talents}

Personnel training mode is the way for a school to construct knowledge, ability and quality structure for students, as well as the realization of this structure, it fundamentally rules the characteristics of talent, and reflects the education ideas and education concept. Scientific division knowledge, ability and quality structure elements of applied talents is a precondition for the implementation of applied talents training mode, combining with the above understanding, we have divided applied talents knowledge, ability and quality structure of the elements as follows

Knowledge structure elements. Applied talents should possess the knowledge of professional and general characteristics of communion, we will be newly built undergraduate course colleges and universities of applied talents knowledge structure elements are divided into basic specialized knowledge, professional knowledge, comprehensive knowledge development and instrumental these four categories: (1) the basic knowledge of professional knowledge. Professional knowledge in college students discipline basic course knowledge system, is the foundation of training talents engaged in professional activities necessary knowledge, to cultivate applied talents of professional ability and professional quality plays a very important role in founding.(2) the knowledge of professional development. The professional development of knowledge in the chosen undergraduate courses direction of disciplines and majors course knowledge system, is to cultivate applied talents development ability and professional identification quality need to master the professional theoretical knowledge or practical knowledge, is to cultivate applied talents development ability and comprehensive quality is the necessary premise.(3) comprehensive knowledge. Comprehensive 
knowledge in cross major, interdisciplinary, across departments, and even cross school elective course knowledge system, is to cultivate applied talents public ability and general quality essential theoretical or practical knowledge.(4) the instrumental knowledge. Instrumental knowledge refers to help college students to learn and master the basic knowledge of professional knowledge, professional development and the method of comprehensive knowledge of sexual knowledge, including knowledge of literature retrieval, foreign language, computer networks, such as technical knowledge, and knowledge study method, thinking method and so on. Instrumental knowledge, therefore, is one of the important content of applied talents training knowledge system, it is for the college students' public ability, professional ability and development ability, professional quality and comprehensive quality and promote the development of a very important role in promoting.

The ability structure of the elements. Ability refers to the subjective conditions necessary to complete an activity, is individual's mental characteristics have a direct impact on activity efficiency and smooth completion. According to revised two factor theory of Spearman, and the characteristic requirement of the communion of professional and developmental ability of the applied talents, we divide the applied talent ability structure elements of newly built undergraduate course colleges and universities into three categories: public ability, professional ability, development capacity: (1) the public power; public power belongs to the general ability, it is people's ability to complete any activity indispensable, is the basic ability should be possessed for people to engage in any profession, including learning ability to think, value judgment ability, communication ability, physical and psychological adjustment ability, and ability of information processing, etc.(2) professional ability; professional ability refers to the specialized personnel's basic practical ability in the specific field in the work. The ability can be used in the field of professional post and general, it is a professional basic knowledge, basic skills and professional basic qualities in the field of industry practice in the explicit as a result, it is a professional education system under the foundation of students' career development.(3) the development ability; development capability is based on the professional ability to form a competent professional post demand through reinforcement learning and practice and can help in career transition, the ability of migration. In particular, the development ability is a professional skills in the "essence", "deep" and "wide", "extension" dimensions, is associated with professional interest, emotion, attitude, identity, sense of commitment, the sense of mission, responsibility and other professional spirit, is the need of the development of college students "personalized" in the future.

\section{Questions existing in the mechanical engineering training centre}

Training target is fuzzy, the training content is thin and not enough to linking to the actual production process. Engineering training center in our country mostly began in the original metalworking practice factory, belonging to the mechanical and electrical college of universities. The existing engineering education based on excessive differentiation of discipline makes it unable to adapt to the new situation requiring the integration of integrated formation, training objective and universal applicability. Fuzzy target leads to the limitation of the existing system of engineering training content, most of the college of engineering training is to have a preliminary understanding and perceptual knowledge in industrial production process, typical mechanical and electrical products, the main purpose of the basic level of training is to learn to use common tools, instruments and equipment, hierarchical multiple modules teaching content system was only a prototype. Students find it difficult to stand at the angle of the big industrial production and engineering background to digest what they have learned, it is difficult to understand general industrial production of organic and integrity, learn the product from the market research, development, design, production safety, quality assurance, management, cost accounting, the green environmental protection to the final recovery reproduce the whole process such as lack of in-depth understanding of the real impact on the cultivation of the large engineering and exercise.

Single function orientation, unable to integrate advantages of face-to-face resources. According to the actual situation in our country, we can seen that the engineering training center in 
our country, in the function orientation, gives priority to teaching, along with the help of scientific research, pay little attention to both social production and service. Although some research engineering schools started to try research driving training ways, they failed to substantially expand the function of the engineering training. Application research and development activities are still very few, in interdisciplinary projects as the link of the training content is even rare. In addition, if the engineering training center can not take the initiative to expand service oriented and positive to conduct foreign students' engineering training, on-the-job personnel continuing education training and related engineering technical consulting and advisory services, colleges and universities are hard to win funding support from all walks of life, enhance their hematopoietic function, improve the training conditions.

\section{Summary}

Social development needs to discover knowledge and explore the objective law of research-oriented talents, also need to use professional knowledge and objective law to the actual production, to create direct benefits of applied talents for the society. Newly built undergraduate course colleges and universities should take cultivating applied talents as the main task. Knowledge, ability and quality of applied talents are both the common requirements, and also have personalities. In the cultivation practice of the applied talents, reasonably making sure of knowledge, ability and quality factors of the applied talents is the precondition to smoothly reform of the applied talents training mode of newly built undergraduate course colleges and universities.

\section{Acknowledgements}

Teaching reform of Jiangxi province (JXJG-16-27-2).

\section{References}

[1] Pan Maoyuan, Shi Huixia, the history retraces of applied talents cultivation, "Jiangsu higher education, 2009(1).

[2] Song Boning, Song Xuhong, the classification study of colleges and universities in Shandong province, Shandong university press, 2012.

[3] Wu Zhongjiang, Huang Chengliang, speeding up the construction of the personnel training system focusing on academic and professional degree, China's higher education, 2013(1).

[4] Yin Ningwei, quality inquiry of applied undergraduate talents cultivation, modern education science, 2012 (4).

[5] Wu Jianhua, the application of higher education, the education research, 2013 (4).

[6] Wu Zhongjiang, Li Jianqi, Huang Chengliang, adhering to the five notices, promoting the five changes to cultivate outstanding engineering and technical personnel, the higher engineering education research,2013 (5).

[7] Guan Tianqiu, research and practice of applied talents training mode of the local university undergraduate course, China's higher education,2007(8). 